Б.М. Іващук ${ }^{1}$, Ю.Г. Павлуша ${ }^{1}$, Л.А. Іващук ${ }^{2}$

${ }^{1}$ Харківський національний університет Повітряних Сил ім. І. Кожедуба, Харків

${ }^{2}$ Державна прикордонна служба України, Харків

\title{
АНАЛІЗ ОСНОВНИХ ПАРАМЕТРІВ БЕЗПІЛОТНИХ АВІАЦІЙНИХ КОМПЛЕКСІВ ТАКТИЧНОГО КЛАСУ ЩОДО ВЕДЕННЯ ПОВІТРЯНОЇ РОЗВІДКИ
}

В статті представлено аналіз основних параметрів безпілотних авіаційних комплексів розвідувальноінформаційного характеру, порівняння даних типів БПЛА для виконання завдань за призначенням підрозділів Збройних сил України, Наџіональної гвардії України та Державної прикордонної служби України. Показано, що повітряна розвідка не замінює інших видів розвідки, але значною мірою доповнює їх, встановлюючи разом з ними безперервний ланџюг розвідки і спостереження. Встановлено коефіџієнт виявлення цілі, що дасть змогу порівняти ефективність розвідки та мати постійну інформаційну перевагу.

Ключові слова: безпілотні авіаџійні комплекси, БПЛА, повітряна розвідка, спостереження, коефіцієнт виявлення цілі.

\section{Вступ}

Постановка проблеми. Особливості ведення бойових дій на сучасному етапі розвитку військової справи пов'язані: з підвищенням ролі дистанційного впливу на супротивника; пріоритетом високоточної зброї; діями в умовах поля бою; підвищенням маневрених можливостей підрозділів; зростанням значущості розвідувальних дій.

Одним з важливих показників залишається виявлення цілі, і розпізнавання об’єкту розвідки. Розвиток технічного прогресу призвів до того, що виявити ціль стає все важче, засоби маскування переходять на новий рівень, і перед завданням розвідки постає не просте завдання - правильно, а головне вчасно провести повітряну розвідку (ПР), обробити дані та вчасно передати їх у зацікавлені штаби, так як від цього залежить успішне виконання поставленого завдання.

Аналіз останніх досліджень і публікацій. На сучасному етапі розвитку технічних засобів розвідки БпАК (як їх носій) виконує завдання за єдиним задумом у складі цілісної системи розвідки, яка включає наземні, морські, повітряні та космічні компоненти розвідки, засоби комутації, кореляції, обробки та розподілення розвідувальних даних, а також ефективність застосування розвідувальної авіації в умовах ППО противника [1-4]. Застосування цих типів в збройних конфліктах $є$ ефективним, безпечним i економічно вигідним для виконання бойових завдань по причині безпілотного способу управління, малих геометричних розмірів, низькою тепловою контрастністю, можливістю діяти на гранично малих висотах, тому перед системами розвідки постають все більш складні та багатогранні завдання, пред'являються жорсткі вимоги та набуває розвитку тенденція широкого впровадження безпілотної техніки.

Мета статті - визначення параметрів оцінювання БпАК щодо покращення ефективності ведення повітряної розвідки БпАК тактичного класу.

\section{Виклад основного матеріалу}

Основні параметри БпАК щодо ведення ПР повітряної розвідки можуть бути охарактеризовані показниками ефективності, що визначають:

- загальні властивості іконічних систем;

- особливості відтворення параметрів аероландшафту;

- різкісні параметри систем.

До загальних показників ефективності відносяться: масштаб $1 / \mathrm{m}$ зображення, яке отримане ТЗПР, поперечна ширина захоплення $B$ місцевості, що розвідується, висоти $H_{\max }$ і $H_{\min }$ ведення ПР, припустимий діапазон зміни відношення швидкості до висоти польоту $-\Delta \frac{V_{n}}{H}$, кут огляду $2 \beta$ системи, спектральний діапазон $\Delta \lambda$ роботи, імовірність $P$ розпізнавання об'єктів.

Масштаб зображення характеризує відношення довжини зображення відрізка $\Delta l$ на аерознімку до дійсної довжини $\Delta L$ цього відрізка на місцевості та описаний формулою (1):

$$
\frac{1}{m}=\frac{\Delta l}{\Delta L} \text {. }
$$

Захоплення місцевості $B$ при аерозйомці визначається шириною ділянки, що спостерігається, у напрямку, який перпендикулярний до напрямку польоту літака-розвідника, вираженою в лінійних чи кутових одиницях або в частках висоти. 
Висоти бойового застосування $H_{\max }$ i $H_{\min }$ визначають гранично можливі висоти ведення ПР. Вони залежать від багатьох факторів, наприклад, таких, як необхідні детальність і масштаб зображення, потоку енергії випромінювання (світлового потоку) джерела підсвічування.

Припустимий діапазон зміни $\Delta \frac{V_{n}}{H}$ характеризується відношенням швидкості польоту $V_{\Pi}$ до висоти $H$ польоту ЛА-розвідника з ОЕСПР, де $V_{\Pi}$ і $H$ обумовлені технічними параметрами ОЕСПР. Припустимий діапазон $\Delta \frac{V_{n}}{H}$ визначає граничну швидкість і висоту ЛА в режимі ведення розвідки.

Кут огляду системи $2 \beta$ - це кут у площині, перпендикулярній напрямку польоту, у межах якого відтворюється зображення місцевості, що розвідується. Кут огляду визначає поперечну ширину захоплення місцевості в частках висоти (2). Між $H, 2 \beta, 1 / m$ і $B$ існує тісний зв'язок (рис. 1):

$$
B=2 H \operatorname{tg} \beta \text {. }
$$

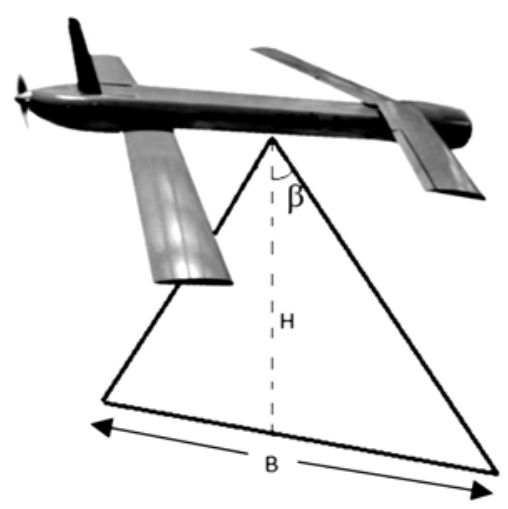

Рис. 1. Зв’язок між кутом огляду, висотою та шириною захоплення місцевості

Джерело: розроблено авторами.

Імовірність розпізнавання $P$ - частота правильного розпізнавання об'єктів (3):

$$
P=\frac{n_{1}}{n_{2}},
$$

де $n_{1}$ - кількість правильно розпізнаних об'єктів;

$n_{2}$ - кількість об’єктів, поданих для розпізнавання.

Імовірність розпізнавання може коливатися в межах від нуля до одиниці. На абсолютне значення ймовірності розпізнавання впливає багато факторів.

Основними 3 них є такі умови одержання аерознімку: висота польоту, характеристики ОЕСПР і фотоматеріалів, умови обробки матеріалів розвідки і т. д. Вважається задовільним результат дешифрування, що характеризується ймовірністю розпізнавання 0,8-0,9 [4].
На рис. 2 наведено типовий маршрут БПАК для виконання завдання пошуку об’єктів у виконавчій зоні [5].

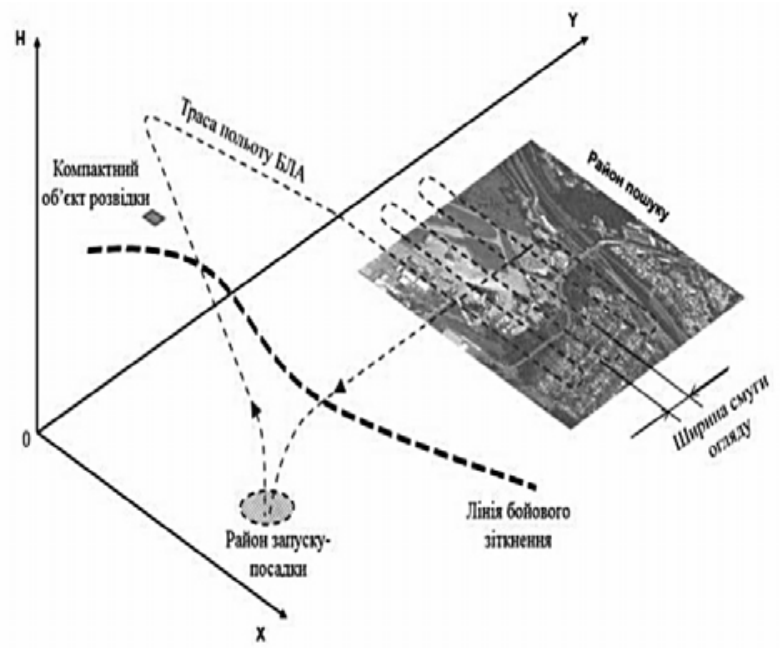

Рис. 2. Приклад маршруту польоту БПАК для виконання завдання пошуку об'єктів у виконавчій зоні Джерело: [5, С. 39].

В умовах технічного прогресу повітряна розвідка (ПР) займає одне із важливих місць, щодо виконання спеціальних задач для силових структур, таких як Збройні сили України (ЗСУ), Національна гвардія України (НГУ), та Державна Прикордонна служба України (ДПСУ). Досвід ведення бойових дій провідних країн світу та під час проведення OОС (АТО) на сході України, показує важливу роль в якості отримання видової інформації ЦОЕС, які розміщуються переважно на БПЛА.

Саме отримання цифрових, а не аналогових зображень починає домінувати при веденні повітряної розвідки.

Розвиток автоматизованих систем управління та зв'язку при передачі даних теж набули розвитку, що дає змогу підвищити оперативність виконання бойових завдань.

Успішність виконання бойових задач залежить від оперативності ведення повітряної розвідки та достовірності отриманої інформації. Чим швидше отримана розвідувальна інформація (PI), тим більша ймовірність випередити противника та знищити його об'єкти. 3 огляду на це, можливо представити послідовність отримання розвідувальної інформації. Важливою вимогою в процесі послідовності отримання PI є оперативність.

Для описання системи виявлення цілі противника можливо застосовувати циклічну модель обгрунтовану на теорії Джона Бойда, яку широко використовують в різних галузях [6].

Схематично, циклічну модель виявлення цілі противника можливо зобразити, як наведено на рис. 3. 


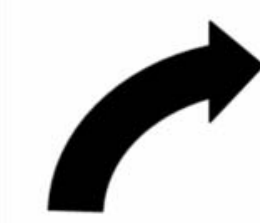

виявлення цілі противника

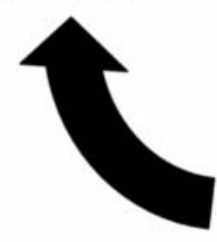

підготовка до ПР

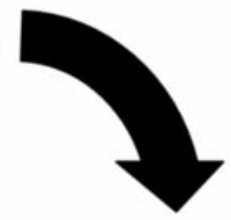

ведення ПІР обробка даних

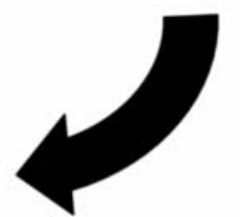

Рис. 3. Циклічна модель виявлення цілі противника

Джерело: [6, С. 72].

Всі ці елементи циклічної моделі виявлення цілі противника пов'язані зв'язками у вигляді стрілок, що представляються засобами зв'язку та автоматизованими системами управління (АСУ). Дана циклічна модель представлена колом, яка являє собою блоки задач, і чим меншим буде коло, тим менший буде час $t$ - оперативність, що $є$ одним із основних параметрів успішного виявлення цілі противника.

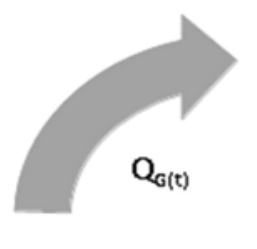

$T_{G}(x)$

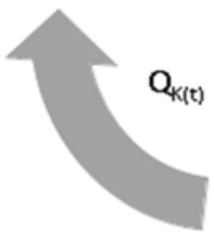

$T_{p}(x)$

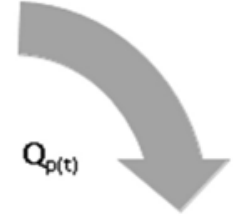

$\mathbf{T}_{\mathrm{H}}(\mathbf{x})$
$T_{k}(x)$

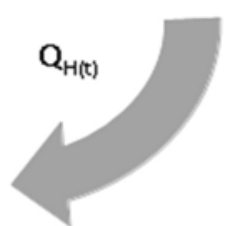

Рис. 4. Оперативність виявлення цілі противника

Джерело: розроблено авторами.

Дана схема на рис. 4 дає можливість порівнювати циклові моделі виявлення цілі противника 3 різними характеристиками комплексів повітряної розвідки, обробки даних, кваліфікації офіцерів штабу. Оперативність виявлення цілі противника залежить від:

1. Часу ведення повітряної розвідки

$$
\left(T_{p}(x)=\{t, d, R, \beta, H, V, a, \ldots\}\right) ;
$$

2. Часу обробки даних інформації

$$
\left(T_{H}(x)=\left\{T_{m p}, T \phi, L \phi, t, \ldots\right\}\right) ;
$$

3. Часу прийняття рішення в штабі

$$
\left(T_{K}(x)=\{K, n, t, \ldots\}\right) ;
$$

\section{4. Часу дії засобів ураження}

$$
\left(T_{G}(x)=\left\{t, D_{y p}, P_{u}, t_{б z}, \ldots\right\}\right) .
$$

Загальна формула оперативності виявлення цілі противника матиме вигляд (4):

$$
\begin{gathered}
T(f(x))=T_{p}(f(x))+T_{Q(P)}(f(x))+T_{H}(f(x))+ \\
+T_{Q(H)}(f(x))+T_{K}(f(x))+T_{Q(K)}(f(x))+T_{G}(f(x)) .
\end{gathered}
$$

Запропонована циклічна модель виявлення цілі противника, дозволяє кількісно оцінити та порівняти комплекси озброєння, відносно оперативності, які планується застосовувати командирами. Зростання нових технологій призводить до покращення тактико-технічних характеристик систем, в свою чергу це підвищує оперативність циклічної моделі виявлення цілі противника.

Кожна силова структура нашої країни виконує певні задачі за призначенням, такі як (наприклад):

- стримування збройної агресії проти України (3СУ);

- припинення терористичної діяльності, збройних формувань, забезпечення громадської безпеки (НГУ);

- здійснення прикордонного контролю (ДПСУ).

\begin{tabular}{|c|c|c|c|c|c|c|}
\hline 放 & $\begin{array}{l}\underline{y} \\
\tilde{\mathbb{E}} \\
\Sigma\end{array}$ & 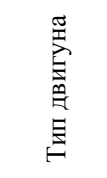 & 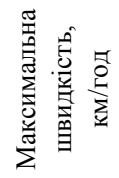 & 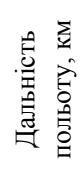 & 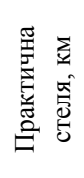 & 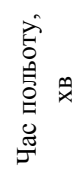 \\
\hline “Фурія” & 4.5 & $\begin{array}{l}\text { елект- } \\
\text { ричний }\end{array}$ & 130 & 50 & 2.5 & 120 \\
\hline "Spectator" & 5.5 & $\begin{array}{l}\text { елект- } \\
\text { ричний }\end{array}$ & 120 & 15 & 2 & 120 \\
\hline $\begin{array}{c}\text { "Лелека- } \\
100 "\end{array}$ & 5 & $\begin{array}{l}\text { елект- } \\
\text { ричний }\end{array}$ & 120 & 100 & 1.5 & 150 \\
\hline "Рейс" & $\begin{array}{l}12 \\
30 \\
\end{array}$ & $\begin{array}{l}\text { TP3- } \\
117\end{array}$ & 900 & 180 & 1 & 13 \\
\hline
\end{tabular}

На озброєнні яких стоять дані представники озброєння і військової техніки, котрі можуть проводити повітряну розвідку (ПР).

Таблиця 1

Тактико-технічні характеристики БпАК

Джерело: розроблено авторами.

На рис. 5 представлено діаграму оперативності від постановки завдання на розвідку, до прийняття рішення штабом по даним ПР від різних засобів БПАК.

На рис. 5 цифрами позначено час етапів підсистем циклічної моделі, де:

1 - час для вильоту; 2 - політ літака; 3 - доставка матеріалів до ЦОРІ; 4 - обробка даних ЦЕОС; 5 - негативна ХФО плівки 120 м; 6 - дешифрування 5 об'єктів; 7 - позитивна ХФО 25 кадрів; 8 - сушка фільму 120 м; 9 - оформлення розвідувального документа; 10 - доставка даних в штаб; 11 - прийняття рішення штабом. 


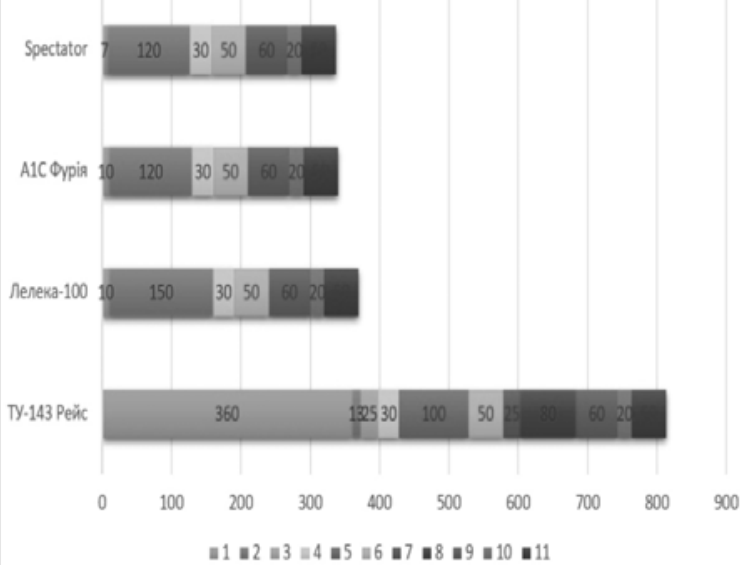

Рис. 5. Діаграма оперативності ПР від різних засобів БпАК

Джерело: розроблено авторами.

Таблиця 2

Час на отримання розвідданих з різних ЛА

\begin{tabular}{|c|c|c|c|c|}
\hline Чис, хв. & : & 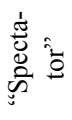 & 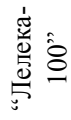 & 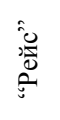 \\
\hline Час для вильоту & 10 & 7 & 10 & 360 \\
\hline Політ літака & 120 & 120 & 150 & 13 \\
\hline Доставка матеріалів до ЦОРІ & & & & 25 \\
\hline Обробка даних ЦЕОС & 30 & 30 & 30 & 30 \\
\hline Негативна ХФО плівки 120 м & & & & 100 \\
\hline Дешифрування 5 об'єктів & 50 & 50 & 50 & 50 \\
\hline Позитивна ХФО 25 кадрів & & & & 25 \\
\hline Сушка фільму 120 м & & & & 80 \\
\hline Оформлення розвід документу & 60 & 60 & 60 & 60 \\
\hline Доставка даних в штаб & 20 & 20 & 20 & 20 \\
\hline Прийняття рішення штабом & 50 & 50 & 50 & 50 \\
\hline $\begin{array}{c}\text { Загальний час для виявлення } \\
\text { цілі }\end{array}$ & 340 & 337 & 370 & 813 \\
\hline
\end{tabular}

Джерело: розроблено авторами.

Аналіз ефективності виявлення цілі безпілотними авіаційними комплексами по оперативності можливо порахувати за коефіцієнтом $K_{6}$ [4].

$$
K_{6}=1-\left(t / t_{\text {доп }}\right),
$$

де $t$ - час виконання завдання;

$t_{\text {до }}$ - допустимий час.

На рис. 6 приведено значення коефіцієнту $K_{e}$ для виконання завдань за розвідувальними даними 3 різних ЛА.

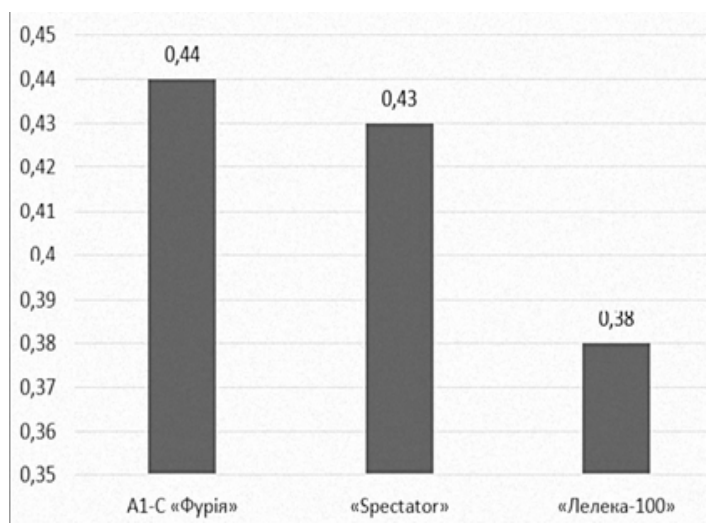

Рис. 6. Графік ефективності виявлення цілі за результатами даних повітряної розвідки з різних типів ЛА

Джерело: розроблено авторами.

Найменш ефективним буде застосування Ту-143 “Рейс" 3 розвідувальним обладнанням, що встановлено на ньому на сьогоднішній день. В нього найбільший час на отримання розвідувальної інформації, тому що сам процес від початку отримання завдання на розвідку, і до виготовлення розвіддонесення включає в себе процес хімікофотографічної обробки (ХФО), який в інших зразках техніки відсутній.

Таким чином, ефективність виявлення цілі буде вищою у взаємодії з БПАК типу А1-С “Фурія", "Spectator".

\section{Висновки}

В даній статті визначено, що застосування нових зразків БпАК з цифровими ОЕС збільшить оперативність виконання завдання до 340 хв. Для цього пропонується закупка нових БПЛА з цифрових ОЕС типу "Spectator", А1-С “Фурія”. Встановлено, що коефіцієнт виявлення цілі застосування засобів ураження 3 А1-С “Фурія”, буде 0,44 ніж у взаємодії 3 БПЛА типу Ту-143 "Рейс".

Таким чином, досвід застосування БпАК в інтересах виконання завдань за призначенням, їх тактико-технічні та експлуатаційні характеристики дозволяють стверджувати, що у сучасних умовах комплектування Збройних сил України, Національної гвардії України, та Державної Прикордонної служби України підрозділами БпАК є вкрай необхідним, і доцільним.

\section{Список літератури}

1. Даник Ю.Г. Концептуальні основи створення і використання систем збору, обробки та аналізу інформації від технічних комплексів (засобів) моніторингу / Ю.Г. Даник // Збірник наукових праць національної академії державної прикордонної служби України. - 2019. - № 2(80). - С. 242-261. https://doi.org/10.32453/3.v80i2.202.

2. Хлоп'ячий В.А. Методика оцінки ефективності застосування розвідувальної авіації / В.А. Хлоп'ячий, Б.М. Іващук, М.В. Пашковський // Збірник наукових праць Харківського національного університету Повітряних Сил. 2020. - № 3(65). - C. 86-90. https://doi.org/10.30748/zhups.2020.65.13.

3. Аналіз мережецентричної моделі застосування засобів ураження по даним повітряної розвідки / Б.М. Іващук, I.М. Зелінський, А.С. Небрат, О.О. Борщевський, О.М. Трисантович // Наука і техніка Повітряних Сил Збройних Сил України. - 2016. - № 3(24). - С. 60-63. 
4. Бзот В.Б. Обробка розвідувальних відомостей $з$ використанням автоматизованих інформаційних систем / В.Б. Бзот, М.В. Мурзін // Збірник наукових праць Харківського національного університету Повітряних Сил. - 2020. № 1(63). - C. 17-21. https://doi.org/10.30748/zhups.2020.63.02.

5. Особливості застосування безпілотного авіаційного комплексу в інтересах підрозділів тактичної ланки Сухопутних військ / Ю.Г. Даник, І.В. Пулеко, Р.М. Осадчук, Д.А. Іщенко // Проблеми створення, випробування, застосування та експлуатації складних інформаційних систем. - 2015. - № 10. - С. 37-42. - Режим доступу: http://nbuv.gov.ua/UJRN/PsvZ 2015_10_6.

6. Іващук Б.М. Аналіз циклічної моделі застосування засобів ураження по даним повітряної розвідки / Б.М. Іващук // Збірник наукових статей слухачів випускних курсів інституту авіації та протиповітряної оборони НУОУ ім. I. Черняховського - 2016. - № 2. - С. 90-92.

7. Алімпієв А.М. Методичні рекомендації щодо застосування підрозділів ЗС України в АТО / А.М. Алімпієв. - Х.: ХУПС, 2014. - $131 \mathrm{c}$.

8. Застосування навігаційних систем та комплексів повітряної розвідки / Б.М. Іващук, В.В. Афанасьєв, С.В. Чорний та ін. - Х.: ХУПС, 2015. - 109 с.

9. Бойовий досвід застосування військових частин та підрозділів родів військ ПС ЗС України / С.С. Дроздов, В.В. Коваль, О.С. Котляр та ін.; за заг. кер. Ю.А. Байдака. - Вінниця: Командування ПС ЗС України, 2015. - 156 с.

10. Основні тенденції створення та застосування груп безпілотних літальних апаратів / В.А. Лупандін, Г.В. Мегельбей, О.Й. Мацько, Т.Л. Куртсеітов, П.О. Міроненко // Наука і техніка Повітряних Сил Збройних Сил України. - 2019. - № 2(35). - C. 88-96. https://doi.org/10.30748/nitps.2019.35.11.

11. Кучеренко Ю.Ф. Аналіз досвіду застосування безпілотних літальних апаратів та визначення напрямку їх подальшого розвитку при веденні мережецентричних операцій / Ю.Ф. Кучеренко, М.В. Науменко, М.Ю. Кузнєцова // Системи озброєння і військова техніка. - 2018. - № 1(53). - С. 25-30. https://doi.org/10.30748/soivt.2018.53.03.

12. Роль, місце, завдання та можливості повітряної розвідки в інформаційному забезпеченні розвідувальнопошукових дій / Б.М. Іващук, Є.І. Амазастов, Ю.С. Калюжний, А.В. Статигін // Збірник наукових праць Харківського національного університету Повітряних Сил. - 2014. - № 1(38). - С. 49-52.

Надійшла до редколегії 02.03.2021

Схвалена до друку 12.05.2021

\section{Відомості про авторів:}

\section{Іващук Богдан Миколайович}

кандидат технічних наук доцент

заступник начальника факультету з наукової

та навчальної роботи - начальник навчальної частини

Харківського національного університету

Повітряних Сил ім. І. Кожедуба,

Харків, Україна

https://orcid.org/0000-0001-9479-6035

\section{Павлуша Юрій Григорович}

курсант Харківського національного університету

Повітряних Сил ім. І. Кожедуба,

Харків, Україна

https://orcid.org/0000-0002-0242-8946

\section{Іващук Ліна Анатоліївна}

інспектор прикордонного контролю

прикордонної служби

відділу ПС "Харків-залізничний”,

Харків, Україна

https://orcid.org/0000-0001-6785-1406

\section{Information about the authors:}

Bohdan Ivashchuk

Candidate of Technical Sciences Associate Professor

Deputy Head of the Faculty of Science

and Educational Work - the Chief Educational Part

of Ivan Kozhedub Kharkiv

National Air Force University,

Kharkiv, Ukraine

https://orcid.org/0000-0001-9479-6035

Yuriy Pavlusha

Cadet of Ivan Kozhedub Kharkiv

National Air Force University,

Kharkiv, Ukraine

https://orcid.org/0000-0002-0242-8946

Lina Ivashchuk

Inspector of Border Control

of the Border Service

"Kharkiv-railway",

Kharkiv, Ukraine

https://orcid.org/0000-0001-6785-1406

\section{ИССЛЕДОВАНИЕ ВОЗМОЖНОСТЕЙ ВЕДЕНИЯ ВОЗДУШНОЙ РАЗВЕДКИ БЕСПИЛОТНЫМИ АВИАЦИОННЫМИ КОМПЛЕКСАМИ ТАКТИЧЕСКОГО КЛАССА}

\section{Б.Н. Иващук, Ю.Г. Павлуша, Л.А. Иващук}

В статье представлен анализ основных параметров беспилотных авиационных комплексов разведывательноинформачионного характера, сравнение данных типов БПЛА для выполнения задач по назначению подразделений Вооруженных сил Украины, Начиональной гвардии Украины и Государственной пограничной службб Украины. Показано, что воздушная разведка не заменяет других видов разведки, но во многом дополняет их, устанавливая с ними непрерывную ичепь разведки и наблюдения. Установлен коэффициент обнаружения цели, что позволит сравнить эффективность разведки и иметь постоянную информачионную преимущество.

Ключевые слова: беспилотные авиационные комплексы, БПЛА, воздушная разведка, наблюдение, коэффициент обнаружения цели. 


\section{RESEARCH POSSIBILITIES OF TACTICAL CLASS AIR INTELLIGENCE OF UNMANNED AERIAL VEHICLES}

B. Ivashchuk, Yu. Pavlusha, L. Ivashchuk

Based on the results of experience in the use of unmanned aerial vehicles in reconnaissance missions, in certain areas revealed some features of combat use of unmanned aerial vehicles in order to ensure the implementation of tasks assigned to units of the Armed Forces of Ukraine, National Guard of Ukraine and State Border Service of Ukraine. Aerial reconnaissance does not replace other types of reconnaissance, but largely complements them, establishing with them a continuous chain of reconnaissance and surveillance. In some cases, aircraft may be the only possible means of obtaining the necessary information about the enemy. In the context of technical progress, air reconnaissance (AR) occupies one of the important places to perform special tasks for law enforcement agencies, such as the Armed Forces of Ukraine, the National Guard of Ukraine, and the State Border Guard Service of Ukraine. The experience of conducting hostilities in the leading countries of the world and during the environmental protection in eastern Ukraine, shows an important role in obtaining species information, which are located mainly on UAVs. It is the acquisition of digital rather than analog images that begins to dominate in aerial reconnaissance. The development of automated control and communication systems for data transmission has also been developed, which makes it possible to increase the efficiency of combat missions. The success of combat missions depends on the efficiency of air reconnaissance and the reliability of the information obtained. The faster intelligence is obtained, the more likely it is to overtake the enemy and destroy his objects. Given this, it is possible to present the sequence of obtaining intelligence information. Thus, the experience of using BPAC in the interests of the assigned tasks, their tactical, technical and operational characteristics allow us to say that in modern conditions of staffing the Armed Forces of Ukraine, the National Guard of Ukraine, and the State Border Guard Service of Ukraine UAVS units are essential.

Keywords: unmanned aerial vehicles, UAVs, aerial reconnaissance, surveillance, target detection rate. 